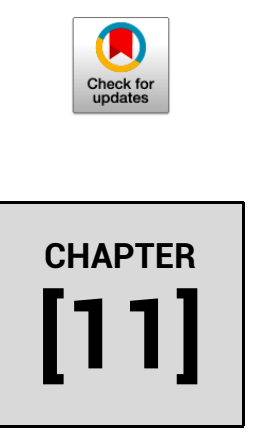

In: Environmental Degradation: Causes and Remediation Strategies

DOI: 10.26832/aesa-2020-edcrs-011

\title{
Management and sustainable energy production using flower waste generated from temples
}

\author{
Vinod Kumar, Sonika Kumari* and Pankaj Kumar
}

Agro-ecology and Pollution Research Laboratory, Department of Zoology and Environmental Science, Gurukula Kangri Vishwavidyalaya, Haridwar-249404 (Uttarakhand), India

Temples are considered as the house of deities. As being a part of their culture, people of Hindu religion pay visits to the temple before starting any auspicious occasion to get blessings of their Gods. Out of them, those who are immense believers of God are the daily visitors of temples. As a part of worship, flowers are essentially used. As a result, a huge amount of flower waste is generated from temples worldwide. The majorly offered flowers in temples include rose, marigold, jasmine, Hibiscus, etc. The flower waste generated from such activities causes harmful effects to many life forms, therefore, its management has become an emerging issue. As flower waste contains enough nutrient and lignocellulosic material, it can be used for a variety of purposes like bioenergy and biofuel production, compost preparation, conditioner for lawn dressing, eco-friendly incense sticks, soaps, rose water and other food products, etc. To achieve sustainable energy demands, low-cost bioenergy can be generated from floral waste. Energy from flower waste either might be in the form of biogas, biohydrogen, bioethanol, biocharcoal, or direct burning to get heat energy. This book chapter deals with a possible consequence that may arise as a result of improper flower waste disposal along with its possible utilization for low-cost bioenergy production and how waste flowers can be used as potential bioenergy material. 


\section{Introduction}

The varied climate of India allows the natural growth of a variety of floral species which are widely used in worshipping places for decoration on various occasions. Various religious rituals are performed in temples in which a variety of items including sweets, leaves, garlands, edible and non-edible fruits, flowers, etc. are offered to Gods (Samadhiya et al., 2017). The waste collected from the temple includes biodegradable and non-biodegradable materials out of which flower waste is segregated due to its biodegradable nature. A huge amount of flower waste is generated at religious places like temples, churches, dargahs because flowers are offered to Gods in almost all religions due to the religious beliefs which afterward are discarded (Yadav et al., 2015). As compared to kitchen waste management, floral waste lacks proper handling strategies (Jadhav et al., 2013). Improper disposal of floral waste in open landfills may result in various health hazards. After a few days of disposal, microorganisms act upon flower waste to degrade it thereby releasing harmful gases. These gases include methane $\left(\mathrm{CH}_{4}\right)$, carbon dioxide $\left(\mathrm{CO}_{2}\right)$, ammonia $\left(\mathrm{NH}_{3}\right)$ and others which create the foul smell and significant contribution to greenhouse emissions (Singh et al., 2017). Dumping of flower waste in water bodies results in a threat to aquatic environments. The aquatic organisms including fishes, diatoms, protozoans, molluscans plankton diversity are significantly affected by such waste disposal practices (Mahindrakar, 2018). On the other hand, pesticides and chemical fertilizers being used for flower cultivation alter the $\mathrm{pH}$ of water bodies resulting in health loss of aquatic bodies. Rotting flowers trigger algal growth in water bodies resulting in eutrophication on a large scale. Increased organic load of the water body by flower waste disposal may tend to grow harmful weeds and microbes which eventually depleting its oxygen levels (Makhania and Upadhyay, 2015). Besides this, nearby drains and water canals connected to such rivers may also get obstructed by flower waste disposal (Maity and Kumar, 2016). With the increase of the human population, the number of visitors is also increasing which consequentially contributing to the enormous amount of flower waste generated (Samadhiya et al., 2017).

To date, most of the holy cities of India including Haridwar, Kedarnath, Katra, Shirdi, Tirupati, Bhubaneswar, Patna, Gaya, Varanasi, etc. have insufficient flower waste disposal policy. Therefore, the management of flower wastes generated in Indian temples has become a cause of environmental pollution (Echavarria-Alvarez and Hormaza-Anaguano, 2014). It is estimated that nearly $40 \%$ of flowers from total production remain unsold and wasted in India and Srilanka. Dumping of flower waste on roadsides and open places gives filthy look to an area and distorts the image of an area especially the places that are regarded as important tourist destinations (Waghmode et al., 2018). As flower waste may have a significant content of lignocellulose, it may act as a good material to produce bioenergy like biogas, biohydrogen, bioethanol, biocharcoal, or 
direct burning to get heat energy. There is a strong need to explore the potential of generated flower wastes from temples and their potential utilization as a feedstock of energy production. Therefore, this book chapter deals with a consequence that may arise as a result of improper flower waste disposal along with its possible utilization for low-cost bioenergy production while addressing how waste flowers can be converted into wealth.

\section{Generation of flower waste in religious places of India}

India is a country of festivals with so many festivals celebrated throughout the year. In all religious places, the flowers are offered to devotees which afterward are discarded and becomes waste (Yadav et al., 2015). Most of the festivals involve worshipping to God including Navratri (celebrated twice in a year) in which nine different forms of the Goddess (Durga) are worshipped. Temples are decorated with flowers of different kinds as well as flowers are offered to Goddess Durga at the time of puja (Yadav et al., 2018). As offered flowers to God are considered as sacrosanct so they are not thrown with other waste generated in hotels, markets, etc. as it hurts the religious sentiments, therefore, are disposed in water bodies or left in open places (Barad and Upadhyay, 2016). The quality and quantity of flower waste generated vary from temple to temple. Gods are worshiped with their favorite flowers as mentioned in Vedas. Besides this, the number of flowers offered also varies from days to days. For example, in temples of Lord Shiva, the amount of flower waste generated is more on Monday and Saturday than other days of the week, Shivratri being Hindu festival generates quite a high amount of flower waste as compared to normal weekdays (Dwivedi et al., 2019). Table 1 shows the status of flowers offered in some selected temples of Chennai as reported by (Perumal et al., 2012). There are nearly 2 million temples in India out of which major temples are in most recognized holy cities including, Haridwar, Kedarnath, Katra, Shirdi, Tirupati, Bhubaneswar, Patna, Gaya, Varanasi, etc. (Ramachandara, 2012). Figure 1 shows some famous temples in India.

\section{Composition of flower wastes}

The composition of flower waste generated vary from place to place like in Dargahs the flower waste mostly consists of jasmine flowers, in Gurudwaras mainly marigold flowers are used and in case of temples marigold, lotus, rose, etc. (Elango and Govindasamy, 2018). Flower wastes are composed of high lignocellulose, cellulose, crude proteins, crude fibers, essential oils, nitrogen-bearing compounds, etc. Such components of flower waste can be utilized as a stock for bioenergy resources. Chrysanthemum flowers are a natural source of flavonoids, volatiles, myricetin and quercitrin (Wu et al., 2010). Jasmine flowers contain essential oils, flavonoids, 


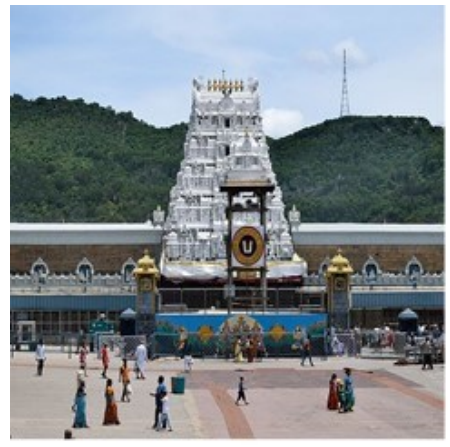

Venkateswara Temple, Tirumala

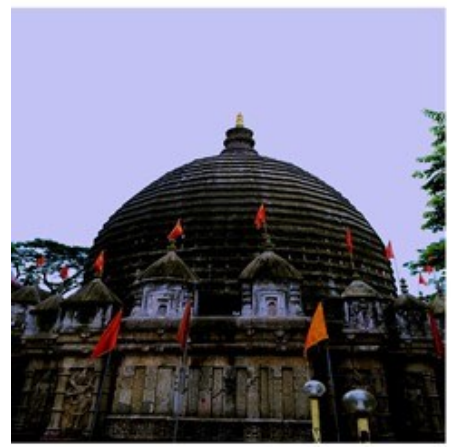

Kamakhya Temple in Guwahati

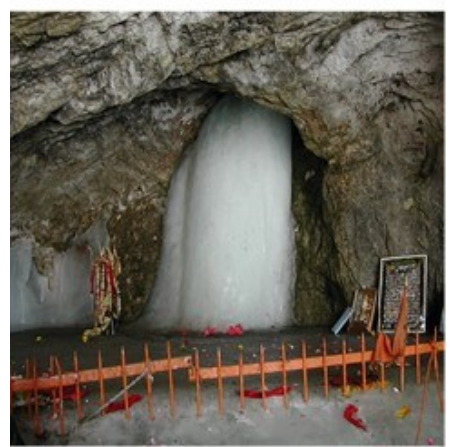

Ice Lingam at Amarnath Cave

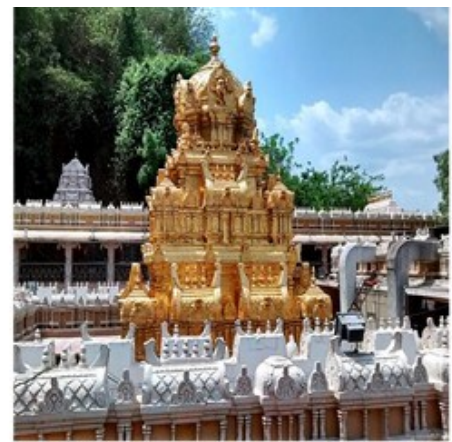

Kanaka Durga Temple

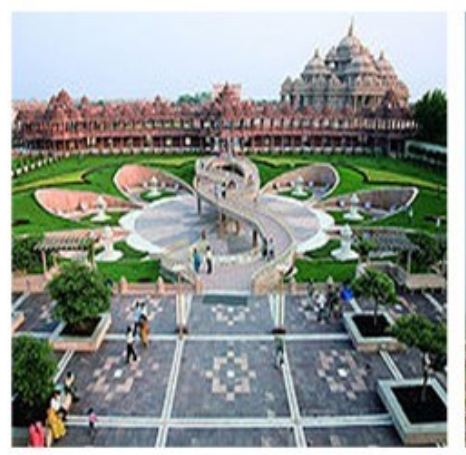

Akshardham

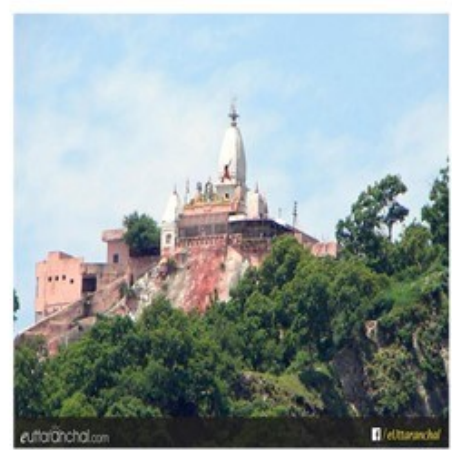

Mansa Devi Mandir, Haridwar

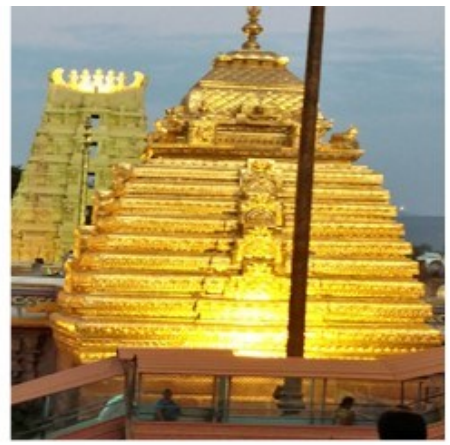

Golden Vimana of Srisailam Temple

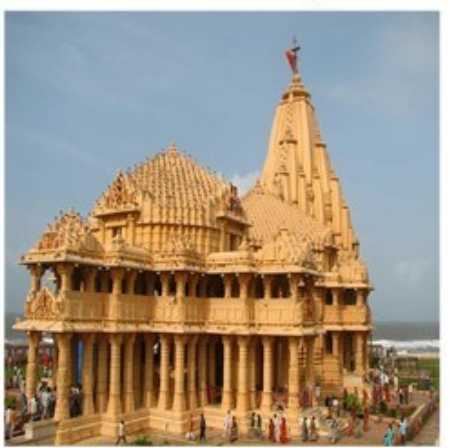

Somnath temple

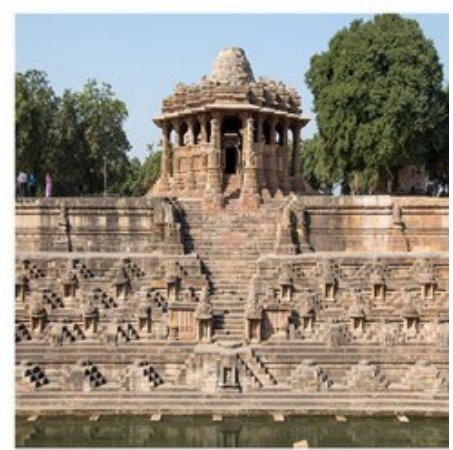

Sun Temple, Modhera

Figure 1. Some famous temples of India. 
Table 1. Status of flowers offered in the selected temples of Chennai (Source: Perumal et al., 2012).

\begin{tabular}{llll}
\hline Temple & Flowers & $\begin{array}{l}\text { Quantity of wasted } \\
\text { flowers (kg per day) }\end{array}$ & $\begin{array}{l}\text { Quantity of flowers } \\
\text { wasted (kg per day) }\end{array}$ \\
\hline $\begin{array}{l}\text { Ashtalakshmi, } \\
\text { Besantnagar }\end{array}$ & $\begin{array}{l}\text { Jasmine, marigold, } \\
\text { rose }\end{array}$ & 1000 & 200 \\
$\begin{array}{l}\text { Marudeeshwar, } \\
\text { Thiruvanmiyu }\end{array}$ & $\begin{array}{l}\text { Jasmine, rose, } \\
\text { chrysanthemum }\end{array}$ & 950 & 125 \\
$\begin{array}{l}\text { Kabaleeshwar, } \\
\text { Mylapore }\end{array}$ & $\begin{array}{l}\text { Rose, marigold, } \\
\text { chrysanthemum }\end{array}$ & 2500 & 800 \\
$\begin{array}{l}\text { Murugan, } \\
\text { Vadapalani }\end{array}$ & $\begin{array}{l}\text { Jasmine, marigold, } \\
\text { rose }\end{array}$ & 1500 & 400 \\
$\begin{array}{l}\text { Sri Parthasarathy, } \\
\text { Light House }\end{array}$ & $\begin{array}{l}\text { Rose, marigold, } \\
\text { chrysanthemum }\end{array}$ & 1200 & 400 \\
\hline
\end{tabular}

phenolics, saponins, and steroids (Kunhachan et al., 2012). Rose flowers are rich in riboflavin, sugars, tannins, pectin, mineral salts, salt of tartaric acid (Thakare et al., 2017). Hibiscus rosa-sinensis contains essential oils, flavonoids, tannins, quinines, phenols, alkaloids, cardiac, protein, carbohydrates, reducing sugars and steroids (Al-Snafi, 2018). Thiophenes, flavonoids, carotenoids, phenolic compounds, and terpenoids are reported in most of the Tagetes species (Gupta and Vasudeva, 2012). Several alkaloids, flavonoids, and non-flavonoid compounds are found in lotus flower (Paudel and Panth, 2015).

\section{Issues in management of flower waste}

Management and handling of flower waste become difficult as compared to the kitchen and other municipal waste because religious sentiments of people are attached with the flowers that are offered to God which afterward becomes part of temple waste (Samadhiya et al., 2017). Because of this, few religious places do not allow to even separate flower waste from temple waste and convert into useful products like making compost, etc. (Jadhav et al., 2013). Mostly flower waste is disposed of in water bodies which result in their deterioration. Due to the decomposition of flower waste dissolved oxygen is depleted from water bodies hence, the death of fishes and other aquatic organisms (Mahindrakar, 2018). Besides this, dumping of flower waste causes landfill problems resulting in surface and groundwater contamination. Due to the biodegradable nature of flower waste, it creates a wrong assumption among people that flower waste degrades fast if it is dumped anywhere despite fast decomposition flower waste decomposes very slowly as compared to kitchen waste (Jadhav et al., 2013). 


\section{Flower waste and bioenergy}

Flower waste can be utilized in several ways to produce bioenergy (Figure 2).

\section{Bioethanol}

Bioethanol produced from flower waste can be blended with other fuels which increase its energy efficiency providing an eco-friendly approach of reduced carbon footprint (Waghmode et al., 2018). Through, saccharification of the reducing sugars obtained from the flower waste may give a promising yield of bioethanol and methanol. However, the pretreatment of flower waste should be optimized as per the composition of waste generated.

\section{Biogas}

Flower waste can also be used as raw material to produce biogas by using anaerobic digestion technology (Lakshmi and Vijayalakshmi, 2017). Methane is a potent greenhouse gas (Singh and Bajpai, 2011), by using flower waste for biogas production, it will help to solve three problems firstly reduced emission of methane in the atmosphere and secondly fulfillment of energy needs and lastly reduced soil pollution from decomposition of flower waste (Rashed and Torii, 2015). The biogas produced from flower waste can be used as a source of heat for cooking purposes or can be used in electricity production (Kulkarni and Ghanegaonkar, 2019). A recent report by Ranjitha et al. (2014) showed that flower waste has enormous potential to produce biogas. The amount of produced biogas per $\mathrm{kg}$ of the substrate from flower wastes in Kenya as reported by them is given in Table 2. Whereas the composition of biogas produced from flower waste is given in Table 3.

\section{Other uses of flower waste}

Other strategies for flower waste management are given below (Figure 2):

Vermicomposting: Being rich in organic matter flower waste can be converted into organic manure by using certain species of earthworm as an alternative to chemical fertilizer. Such ver-

Table 2. Amount of biogas (per kg substrate) produced from flower wastes in Kenya (Source: Ranjitha et al., 2014).

\begin{tabular}{ll}
\hline Substrate & Biogas (per kg of substrate) \\
\hline African wattle & 10.92 \\
Roselle & 5.18 \\
Nile tulip flower & 5.38 \\
Silk tree mimosa & 23.73 \\
Sunset flower & 2.73 \\
Jasmine & 6.07 \\
\hline
\end{tabular}


Table 3. Analysis of biogas generation (volume) from flower waste (Source: Singh and Bajpai, 2011).

\begin{tabular}{llll}
\hline Months (year) & Methane (\%) & Carbon dioxide (\%) & Other gases (\%) \\
\hline December (2009) & 43 & 50 & 7 \\
January (2010) & 44 & 50 & 6 \\
February (2010) & 50 & 44 & 6 \\
March (2010) & 50 & 43 & 7 \\
April (2010) & 52 & 42 & 6 \\
May (2010) & 54 & 40 & 6 \\
\hline
\end{tabular}

Table 4. Physico-chemical characteristics of floral waste vermicompost (Source: Jain, 2016).

\begin{tabular}{lll}
\hline Parameters & Control (Soil) & Vermicompost (50:50) \\
\hline Color & Dark Brown & Black \\
Odor & Odorless & Odorless \\
Moisture & 20.50 & 22.80 \\
Bulk Density $(\mathrm{g} / \mathrm{cm} 3)$ & 0.88 & 0.89 \\
$\mathrm{pH}$ & 7.9 & 7.0 \\
Conductivity $(\mathrm{ms} \mathrm{cm}-1)$ & 3.50 & 3.35 \\
Organic Carbon & 16.5 & 19.4 \\
Total Nitrogen & 0.90 & 2.0 \\
C/N ratio & 20.0 & 21.55 \\
Total Phosphorus $\left(\mathrm{P}_{2} \mathrm{O}_{5}\right)$ & 2.57 & 2.0 \\
Potassium $\left(\mathrm{K}_{2} \mathrm{O}\right)$ & 0.4 & 0.9 \\
Calcium & 4.4 & 5.9 \\
Magnesium & 0.2 & 0.3 \\
Sulphur & 0.40 & 0.50 \\
\hline
\end{tabular}

micompost may be helpful to provide nutrient-conditioning to the soil (Sharma and Yadav, 2017). Due to the presence of a higher value of nitrogen-phosphorus-potassium in flower degradation material, it can also be used as NPK fertilizer. The microbial consortium can be prepared from flower waste in order to avoid the problems of flower waste generated (Jadhav et al., 2013). Table 4 provides characteristics of flower waste vermicompost as analyzed by in study of Jain (2016).

Food products: Edible waste flowers such as roses and marigolds are rich in nutrient, therefore, can be used for making syrups, cakes, ice creams, cookies, jellies, jams, sweets, beverages, etc. by food industries (Waghmode et al., 2018).

Biochar: The woody part of flower waste can be converted into biochar through the process of slow pyrolysis (Bogale, 2017). Biochar can be further used as a material for absorption or adsorption of heavy metals and other harmful substances resulting in purification of wastewater (Waghmode et al., 2018). 
Table 5. Composition of essential oil of Rosa damascene obtained from GC-MS analysis (Source: Perumal et al., 2012).

\begin{tabular}{|c|c|c|}
\hline Peak area $(\%)$ & Components & Retention time (sec) \\
\hline 0.07 & Benzaldehyde & 3.189 \\
\hline 27.19 & Phenyl ethyl alcohol & 4.775 \\
\hline 0.15 & Tetradecanol & 5.394 \\
\hline 1.44 & Propanamide & 5.452 \\
\hline 0.01 & Phenyl ethyl ester & 5.703 \\
\hline 3.12 & Thiophene carboxylic ester & 6.457 \\
\hline 0.23 & methyl 4-pentanyl acetyl ester & 7.733 \\
\hline 0.19 & Hexadecanol & 8.11 \\
\hline 0.29 & Ethyl amino 1- butyl cyclohexa benzene & 9.091 \\
\hline 0.08 & Bromo propionate & 9.097 \\
\hline 0.55 & 2-2-dimethyl phenyl ethyl ester & 10.595 \\
\hline 0.19 & Tricosene & 11.243 \\
\hline 0.36 & Heptyle 2-phenyl ethyl ester & 12.316 \\
\hline 0.27 & Isohexyl ester & 12.452 \\
\hline 0.10 & 8-methyl heptacosane & 13.099 \\
\hline 0.21 & Eicosane & 14.801 \\
\hline 0.14 & Pentatriacontene & 16.068 \\
\hline 3.17 & Nonadecene & 16.209 \\
\hline 7.76 & Hexadecane & 16.744 \\
\hline 0.72 & Benzene propaonic ester & 17.402 \\
\hline 0.09 & Eicosene & 18.098 \\
\hline 1.11 & Phenyl Dodecanoic ester & 18.562 \\
\hline 0.17 & Di phenyl ethyl ester & 19.703 \\
\hline 0.20 & Octadecyl tri chloro ethyl ester & 19.887 \\
\hline 0.35 & Heneicosanol & 20.167 \\
\hline 0.21 & Chloropropronic ester & 20.235 \\
\hline 10.49 & Heneicosane & 20.316 \\
\hline 0.11 & Hexadecyleste & 21.995 \\
\hline 0.27 & 2Propyl tridecyl ester & 22.682 \\
\hline 0.54 & Dodecanoic ester & 23.29 \\
\hline 1.15 & Tricosane & 23.629 \\
\hline 1.89 & Tetratetracontene & 23.764 \\
\hline 0.48 & Cyclobutyl pentadecyl ester & 25.379 \\
\hline 0.21 & Pentadecyl 2-phenyle ethyle tridecyle ester & 26.655 \\
\hline 3.03 & Pentatriacontene & 26.752 \\
\hline 2.73 & Chloropropionic ester & 26.848 \\
\hline 0.15 & Benzene dicarboxylic ester & 26.955 \\
\hline 3.45 & Tetra methyl trisilocendecanol & 27.602 \\
\hline
\end{tabular}


Table 5. continued...

\begin{tabular}{lll}
\hline 0.23 & Dimethyle benzaldehyde thiocarbamoyl hydrazon & 27.718 \\
0.70 & Pthalic diphenyl ester & 28.037 \\
0.31 & Hexacosane & 28.124 \\
0.19 & Dibromoecosane & 28.18 \\
0.48 & Octadecyle ester & 28.88 \\
0.39 & Cyclotrisiloxane & 29.495 \\
0.22 & Benzamine & 29.536 \\
0.39 & Methoxyethyl ester & 29.594 \\
0.84 & Hexadecane-l-ol acetate & 29.72 \\
0.61 & Cyclobutane & 30.068 \\
0.44 & Nonacosane & 30.909 \\
0.70 & Cyclohexadiene & 30.977 \\
0.32 & Trimethyl silyl ester & 31.073 \\
5.77 & Phenyl ethyl tetradecyl ester & 31.275 \\
0.52 & Thiophene & 31.85 \\
0.32 & Hexadecyl 2-phenylethyl ester & 32.6 \\
\hline
\end{tabular}

Essential oil extraction: In India, around 300,000 metric tons of flowers are being utilized for various purposes like making garlands, decorations, pigments extraction, insecticides, and perfume ingredients. The flowers offered to deities are available as temple flower waste among which rose was found to be $50 \%$ so can be used for extraction of essential oils (Perumal et al., 2012). About 300 compounds are present in rose oil. Perumal et al. (2012) studied the composition of essential oil in Rosa damascene (Table 5).

Dye extraction: Colored pigments present in flowers give them characteristic color which attracts the eyes of the viewer. The pigments from colored flowers are extracted to further used in a variety of purposes like:

- For dyeing fabrics in the textile industry.

- Making colored candles.

- $\quad$ Food industry for making eggs, vegetables, etc. colored.

- Making colors in powdered form by using solar drier for drying flowers which can be used as Holi and Rangoli colors, being purely organic is safe to use (Kumar et al., 2016).

Medicinal uses: Some flowers from temple flower waste such as marigold, Hibiscus rosa sinensis have medicinal properties so can be utilized for the medicinal purpose that is mostly taken in the form of decoction (Voon et al., 2011).

Essence: Essence can be extracted from flowers. These are kind of infusions made from flowers by boiling them, there is no physical part of the flower. Flower essence has wide utility it can be used in beauty products, shampoos, lotions, aromatherapy, etc. (Ali et al., 2015). 


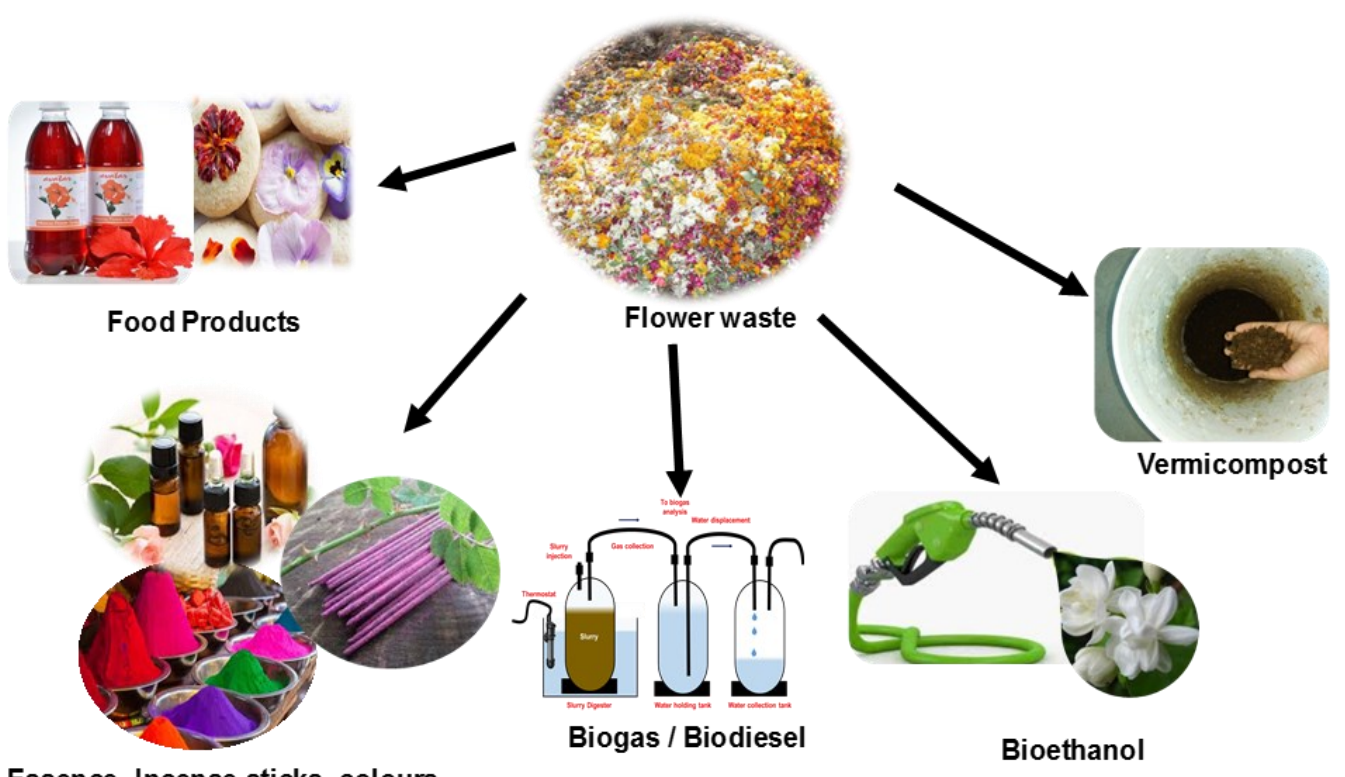

Essence, Incense sticks, colours

Figure 2. Use of flower waste feedstock as a resource for production of bioenergy and other useful materials.

Miscellaneous uses: Incense stick making and handmade paper production are being carried out by using waste flowers moreover dry flowers can be used for various art and craft activities. Some flowers can also be used as veterinary feed. Nowadays activated carbon is being prepared from temple flower waste which has a wide range of utility due to its adsorption properties (Elango and Govindasamy, 2018).

\section{Conclusion and recommendations}

This chapter deals with the problems of flower waste generated at religious places. Improper handling and disposal of flower waste cause serious problems affecting the soil, water and air quality of the nearby environment. However, flower waste is a good source of lignocellulose and organic matter, therefore, it can be used as a potential resource for bioenergy production and other useful products. By using flower waste, a significant amount of bioenergy can be produced, which may serve a dual purpose by helping in reducing the environmental problems and giving us eco-friendly energy at a low cost. Besides bioenergy production, many other compounds can also be extracted from flower waste which has great demand by industrial sectors. Thus, this book chapter emphasized on the utilization of flower waste generated from temples as a potential 
resource for bioenergy production to meet future goals of sustainable energy production.

\section{Acknowledgments}

This work was academically supported by the Department of Zoology and Environmental Science, Gurukula Kangri Vishwavidyalaya, Haridwar, India. The Corresponding author (S.K) is grateful to her lab mates for their support and guidance at each step.

\section{References}

Ali, B., Wabel, A.A.N., Shams, S., Ahamad, A., Khan, S. A. and Anwar, F. (2015). Essential oils used in aromatherapy: A systemic review. Asian Pacific Journal of Tropical Biomedicine, 5(8): 1-11, https://doi.org/10.1016/j.apjtb.2015.05.007

Al-Snafi, A.E. (2018). Chemical constituents, pharmacological effects and therapeutic importance of Hibiscus rosa-sinensis- A review. IOSR Journal of Pharmacy, 8(7): 1-5.

Barad, G. and Upadhyay, A. (2016). Degradation of flower wastes: A review. International Journal for Scientific Research \& Development, 4(4): 1-2.

Bogale, W. (2017). Preparation of charcoal using flower waste. Journal of Power and Energy Engineering, 5: 1-10, https:// doi.org/10.4236/jpee.2017.52001

Dwivedi, A., Dubey, R.P.K., Singh, P.K. and Ohri, A. (2019). Scientific management of municipal solid waste in an academic campus - A case study of IIT(BHU). Journal of Materials and Environmental Sciences, 10(10): 1-9.

Echavarria-Alvarez, A.M. and Hormaza-Anaguano, A. (2014). Flower wastes as a low-cost adsorbent for the removal of acid blue 9. Dyna, 81(185): 1-7, https:// doi.org/10.15446/dyna.v81n185.37234

Elango, G. and Govindasamy, R. (2018). Analysis and utilization of temple waste flowers in Coimbatore District. Environmental Science and Pollution Research, 25(11): 1- 7, https://doi.org/10.1007/s11356-018-1259-0

Gupta, P. and Vasudeva, N. (2012). Marigold -A potential ornamental plant drug. Hamdard Medicus, 55(1): 1-15. International Journal of Engineering Technology Science and Research, 2: 1-6.

Jadhav, A.R., Chitanand, M.P. and Shete, H.G. (2013). Flower waste degradation using microbial consortium. IOSR Journal of Agriculture and Veterinary Science, 3(5): 1-63.

Jain, N. (2016). Waste management of temple floral offerings by vermicomposting and its effect on soil and plant growth. International Journal of Environmental \& Agriculture Research, 2(7): 1-6.

Kulkarni, M.B. and Ghanegaonkar, P.M. (2019). Methane enrichment of biogas produced from floral waste: A potential energy source for rural India. Energy Sources, Part A: Recovery, Utilization, and Environmental Effects, 41(22): 1-12.

Kumar, P., Sachan, A.K. and Rawat, A. (2016). Utilization of temple flower waste in Varanasi for the generation of economic resources. Journal of Environmental Sciences and Engineering, 1(3): 1-8.

Kunhachan, P., Banchonglikitkul, C., Kajsongkram, T., Khayungarnnawee, A. and Wichet Leelamanit, W. (2012). Chemical composition, toxicity and vasodilatation effect of the flowers extract of Jasminum sambac. Hindawi Publishing Corporation, pp. 1-7, https://doi.org/10.1155/2012/471312

Lakshmi, C. and Vijayalakshmi, S. (2017). Studies on biogas production using withered flowers as a substrate. Research Journal of Pharmacy and Technology, 10(12): 1-4, https://doi.org/10.5958/0974-360X.2017.00773.9

Mahindrakar, A. (2018). Floral waste utilization. International Journal of Pure and Applied Bioscience, 6(2): 1-5.

Maity and Kumar P. (2016). Impact of waste flower on environment. International Journal for Research in Applied Science $\mathcal{E}$ Engineering Technology, 4(8): 1-2.

Makhania, M. and Upadhyay, A. (2015). Study of flower waste composting to generate organic nutrients. International Journal of Innovative and Emerging Research in Engineering, 2(2): 1-5. 
Paudel, K.R. and Panth, N. (2015). Phytochemical profile and biological activity of Nelumbo nucifera. Hindawi, pp. 1-16.

Perumal, K., Sambanda, T. and Savitha, J. (2012). Characterization of essential oil from offered temple flower Rosa damascena mill. Asian Journal of Experimental Biology and Science, 3: 1-5.

Ramachandara, S.K. (2012). Vastu-Silpa Kosha, Encyclopedia of Hindu Temple architecture and Vastu by S.K. Ramachandara Rao (Ed.), Delhi, Devine Books, (Lala Murari Lal Chharia Oriental series), Volume 3, pp. 485.

Ranjitha, J., Vijayalakshmi, S.,Vijayakumar, P. and Ralph, N.(2014). Production of biogas from flowers and vegetable wastes using anaerobic digestion. International Journal of Research in Engineering and Technology, 3: 1-5.

Rashed, M. and Torii, S. (2015). Removal of hydrogen sulfide $\left(\mathrm{H}_{2} \mathrm{~S}\right)$ from biogas using zero-valent iron. Journal of Clean Energy Technology 3(6): 1-5, https://doi.org/10.7763/jocet.2015.v3.236

Samadhiya, H., Gupta, R.B. and Agrawal, O.P. (2017). Disposal and management of temple waste: Current status and possibility of vermicomposting. International Journal of Advanced Research and Development, 2(4): 1-8.

Sharma, D. and Yadav, K. D. (2016). Bioconversion of flowers waste: Composing using dry leaves as bulking agent. Environmental Engineering Research, 22(3): 1-8, https:/ / doi.org/10.4491/eer.2016.126

Singh, P. and Bajpai, U. (2011). Anaerobic digestion of flower waste for methane production: An alternative energy source. Environmental Progress \& Sustainable Energy, 1-5, https://doi.org/10.1002/ep.10589

Thakare, P.A., Deshbhratar, K. and Suryawanshi, M.N. (2017). A brief review on therapeutic effects of - "ornamental plant" rose. International Journal of Ayurveda and Pharma Research, 5(12): 1-7.

Voon, H.C., Bhat, R. and Rusul, G. (2011). Flower extracts and their essential oils as potential antimicrobial agents for food uses and pharmaceutical applications. Comprehensive Reviews in Food Science and Food Safety, 11(1): 1-22, https:// doi.org/10.1111/j.1541-4337.2011.00169.x

Waghmode, M.S., Gunjal, A.B., Nawani, N.N. and Patil, N.N. (2018). Management of floral waste by conversion to valueadded products and their other applications. Springer, 9(1): 1-11, https://doi.org/10.1007/s12649-016-9763-2

Wu, L.Y., Gao, H.Z., Wang, X.L., Ye, J.H., Lu, J.L. and Liang, Y.R. (2010). Analysis of chemical composition of Chrysanthemum indicum flowers by GC/MS and HPLC. Journal of Medicinal Plants Research, 4(5): 1-6.

Yadav, I., Juneja, S.K. and Chauhan, S. (2015). Temple waste utilization and management. International Journal of Engineering Technology Science and Research, 2: 1-6.

Yadav, I., Singh, S., Juneja, S.K. and Chauhan, S. (2018). Quantification of the temple waste of Jaipur city. Recent Trends in Agriculture, Food Science, Forestry, Horticulture, Aquaculture, Animal Sciences, Biodiversity, Ecological Sciences and Climate Change, pp. 1-3.

$\star \star \star \star * *$

Cite this chapter as: Kumar, V., Kumari, S. and Kumar, P. (2020). Management and sustainable energy production using flower waste generated from temples. In: Environmental Degradation: Causes and Remediation Strategies, Volume 1, Eds. Kumar, V., Singh, J. and Kumar, P., pp. 154-165, https://doi.org/10.26832/aesa-2020-edcrs-011 